\title{
Analysis of Mathematics Problem Solving Ability Based on Contextual Teaching and Learning Models Assisted by Macromedia Flash on Private Junior High School Students Al-Hikmah Medan
}

\author{
Muhammad Arief Rivai ${ }^{1, *}$ Bornok Sinaga $^{2}$ Ani Minarni $^{3}$ \\ ${ }^{1,2,3}$ State University of Medan \\ ${ }^{*}$ Corresponding author. Email: muhammadariefrivai@gmail.com
}

\begin{abstract}
This study aims to analyze: (1) the level of problem-solving ability in terms of the Contextual Teaching and Learning model of the Al-Hikmah Private Junior High School students in Medan., (2) the answer process of the Al-Hikmah Private Junior High School students in Medan based on the Contextual Teaching and Learning model, and (3) the difficulties experienced by the students of Al-Hikmah Private Junior High School Medan in solving problems of problem solving abilities based on the Contextual Teaching and Learning model assisted by Macromedia Flash. The research subjects were in class VIII-4 of Al-Hikmah Private Junior High School Medan, totaling 35 students. The instrument of this research is a test of mathematical problem solving ability, and an interview guide. Data analysis was carried out using the Miles and Huberman model. The results showed: (1) The ability to solve mathematical problems found that there were 3 students $(8.57 \%)$ who had a high level of mathematical problem solving ability; 11 students $(31.43 \%)$ have a moderate level of mathematical problem solving ability; 21 students (60\%) have a low level of mathematical problem-solving ability. While the problem- solving indicator in the form of understanding the problem is more dominant with a percentage of $48.5 \%$ achieved by students for this indicator, this proves that students are able to understand the problem of the problem, meaning that students able to make known and asked from the question. Then on the indicator of planning solutions, $45.7 \%$ of students were able to plan problem solving from the problem and for indicators of solving problems it was found that the percentage of $25.7 \%$ of students were able to solve the problem accompanied by a logical reason and for the indicator to check again it was obtained $0 \%$ in terms of concluding, this is because most students do not provide conclusions on solving problems, (2) the difficulties experienced by students in solving mathematical problem solving using the contextual teaching and learning model have difficulties in understanding concepts, difficulties in applying principles, and also difficulties in verbal problems.
\end{abstract}

Keywords: Mathematical Problem Solving Ability, Contextual Teaching and Learning, Macromedia Flash.

\section{INTRODUCTION}

Advances in science and technology require someone to be able to master information and knowledge. According to Hasratuddin (2015) said that "to be able to master the information and knowledge required an ability to obtain, select and process information". These abilities require critical, systematic, logical, and creative thinking.

There are many reasons why students need to learn mathematics. According to Hasratuddin (2014) that "mathematics is a way of using information, using knowledge about shapes and sizes, using knowledge about counting, and most importantly thinking in humans themselves in seeing and using relationships". Cornelius (in Purba, 2017) suggests that: Five reasons for the need to learn mathematics because of mathematics, namely (1) a clear and logical means of thinking, (2) a means to solve problems of everyday life, (3) a means of recognizing patterns of relationships and generalization of experience, (4) means to develop creativity, and (5) means to increase awareness of cultural development. 
One of the skills that are the focus of learning that is important for students to have is the ability to solve problems and mathematical communication. Problem solving is one of the important components of the eight objectives of learning mathematics. As revealed by Hudiono (in Tiun 2013) that in the framework of the assessment dimensions, problem solving, which is one component of the mathematics learning process, is included as a component of mathematical ability.

Hudiono (2007) argues that "problem solving is a complex cognitive activity involving a number of processes and strategies". In problem solving, there are various alternative answers. Mathematics is basically problem solving, therefore mathematics should be taught through various problems that exist around students by taking into account the age and experience that students may have. Thus, improving understanding ability can be applied in learning mathematics through problem solving.

The results of Sumarmo's study (in Ratnaningsih, 2017) concluded that "the problem- solving skills of high school students or junior high school students are still low". In line with that, the results of Fakhrudin's (2010) research on junior high schools (SMP) 'in general, the results of the mathematical problem solving abilities of junior high school students have not been satisfactory, around $30.67 \%$ of the ideal score'. Problem solving ability is closely related to students' ability to read and understand the language of story questions, present in mathematical models, plan calculations from mathematical models, and complete calculations from non-routine questions.

From the observations of researchers, various obstacles may occur in the field in terms of facilities, environment, and learning activities that are usually carried out still teacher-centered, students tend to be passive in the learning process. Most teachers still use the lecture method in delivering learning. Ruseffendi (2010) argues that "any activity carried out by lecturing (listening) will be remembered by only $20 \%$ of students, if it is conveyed through sight it can be remembered by $50 \%$ of students, and if an activity is carried out by doing it will be remembered by students of $75 \% "$.

The activity that is most often carried out by teachers is usually a learning method where the teacher provides material, then the activity of students is listening. Then, the teacher explains examples of practice questions so the students' activities see. Continuing to provide practice questions that are almost the same as examples or routine questions, the student's activities are carried out. The process of this activity results in a process of memorizing procedures or concepts, when faced with problems that are not routine or complex, students tend not to be able to solve problems.
Based on this, it is necessary to have innovations in mathematics learning to improve students' problem solving and mathematical communication skills. Problem solving and mathematical communication skills of students are one of the strengths that are the goals of learning mathematics at the high school level which provide great opportunities for students to be able to solve problems related to everyday life and communicate mathematical ideas in order to increase the competencies that must be possessed. in the future. When someone learns mathematics to understand concepts, that's when that person pioneers other mathematical thinking abilities.

So that students have mathematical problem solving skills, the teacher organizes schools not to teach but to how students learn such as helping and encouraging students to study hard, motivating students to be more diligent in learning, how to formulating questions, how to discuss and find answers to problems and so on. In learning activities so far students only receive material from the teacher so that more notes and memorizes it which makes learning meaningless so students feel bored. It is said that a learning that starts with a problem will change the learning that has been teacher- centered to student-centered by using Macromedia Flash will attract students' attention and motivate students in learning activities.

Thus, it is changed towards seeking and finding knowledge so that there is an increase in understanding of the material being studied with the Macromedia Flash. This learning provides active learning conditions for students through solving a problem, where students learn knowledge from the given problem. Therefore, students should be given practice and get used to solving problems.

In this case, the teacher can use contextual- based learning assisted by Macromedia Flash which is expected to create a pleasant learning situation, encourage students to learn and provide opportunities for students to construct the concepts learned so as to achieve good student learning outcomes. By giving a problem to students it will raise their curiosity, how to solve it, what concepts are needed for solving them and what methods are appropriate for solving them. This will encourage students to use the knowledge they already have and look for what they need to know to solve the problem. This learning will make students better understand mathematical concepts and know problem solving procedures so that students are skilled in solving math problems and the performance and variety of answers from students will be better.

Contextual-based learning assisted by Macromedia Flash makes students become independent learners, meaning that when students learn, they can choose appropriate learning strategies, are skilled at using these strategies to learn and are able to control the learning 
process, and are motivated to complete their learning. Contextual-based learning assisted by Macromedia Flash will lead students to understand the concept of subject matter and know problem solving procedures starting from learning and working on problem situations given at the beginning of learning, so that students gain the freedom to think about finding solutions to the problems given. Through the learning experiences that students gain through work activities, searching and finding for themselves will not be easy to forget.

Based on the facts in the field, the learning process that teachers tend to do is simply convey learning using the lecture method while students take notes in notebooks, question and answer and assignments as a result students only listen, pay attention to teacher explanations and complete assignments so that there is less interaction between fellow students and students. teacher. Based on the data obtained from class VIII students of the AL- Hikmah Private Junior High School Medan in the 2018/2019 academic year, it appears that student learning outcomes in mathematics are still low, this can be seen from the semester exams with the average grade VIII semester exam results being only 50 while the KKM is only 50. set is 70 . (source of student report cards for 2017/2018 semester 1).

The results of the preliminary research in grades VIII-9 of Al-Hikmah Private Junior High School Medan where mathematical problem solving ability is based on four aspects of indicators, namely understanding the problem, planning solutions, implementing the solution plan, and re-examining the solution, which is still relatively low, which is stated as follows:

From the process of answering the low- ability category, it turns out that students can only answer modestly (providing one solution) so that from the aspect of planning and implementing indicators it is still in the less category, in the aspect of checking again in the very poor category.

From the results of the student's mathematical problem solving ability test, it turned out that it was still very low. Many factors are the cause of the low mathematical problem solving ability of students, including the ability of a person to understand and absorb lessons. According to Chatib (2016: 100) that "there are students who are fast, moderate, and there are also students who are very slow. Therefore, they often have to take different ways to understand the same information or lesson." There are students who prefer to write things that have been conveyed by the teacher during the learning process. There are also students who prefer to listen to the material presented by the teacher and there are students who prefer to practice directly.

One of the factors causing the low ability to solve mathematical problems is influenced by the learning used by the teacher. The learning process does not deliver student-centered learning will give a bad impression, because learning occurs only in one direction so that students do not find their own learning concepts and make learning meaningless. This resulted in problem solving, the variety of student answers and students' attitudes towards mathematics were very alarming, this should be changed. The change was made by placing more emphasis on solving mathematical problems.

Basically, every student has different abilities in understanding, understanding, analyzing, well the elements that exist in mathematics. The use of various symbols and various formulas, according to students, is to focus their thoughts more so that they can master concepts and procedurals in mathematics by giving problems to students.

\section{LITERATURE REVIEW}

\subsection{Problem Solving Ability}

Problem solving ability is a student's ability that must be possessed because it can apply previously acquired knowledge into new situations. According to Wardhani (in Delyana, 2015) said that "problem solving ability is the ability to apply previously acquired knowledge into new situations that are not yet known". Previously, students had gained knowledge from the teacher, so that students who had problem solving skills were able to apply appropriate strategies when solving math problems.

Problem solving skills need to be mastered by students because they can find patterns in mathematics, apply rules in mathematics through problem solving activities. According to Suherman (in Masrurotullaily, et al, 2013) that "mathematical problem solving ability is one of the abilities that students need to master because through problem solving activities, aspects of important mathematical abilities such as applying rules to nonroutine problems, finding patterns and others. others, can be developed better".

\subsection{Problem Solving Ability Indicator}

In solving mathematical problems, there are several steps, according to Polya (in Susanto, 2016) which states that there are four steps in problem solving, namely:

1. Understand the problem. This step includes:

- what is known, what information is given, or how is the information about the question;

- whether the information provided is sufficient to search for what is being asked;

- whether the information is insufficient, the information is redundant;

- draw appropriate drawings or notations. 
2. Planning a solution. This step consists of:

- have you come across questions like this before, have there been similar questions in other forms;

- which formula can be used in this problem;

- pay attention to what is asked;

- $\quad$ get the results and methods then used here.

3. Through calculations. This step emphasizes the implementation of the completion plan which includes:

- $\quad$ check each step whether it is correct or not;

- how to prove that the selected steps are correct;

- carry out calculations in accordance with the plans made.

4. Recheck the process and results. This step emphasizes how to check the correctness of the answers obtained, which consist of:

- $\quad$ can the answer be checked for correctness;

- can the answer be sought in another way;

- can the answer or method be used for other questions.

\subsection{Contextual Teaching and Learning (CTL)}

In order to avoid misunderstandings about the definition of CTL, it is necessary to explain the meaning of Contextual Teaching and Learning (CTL) which is meaningful, meaningful and meaningful learning in the world of education. Contextual Teaching and Learning (CTL) according to Elaine B. Johnson are:

Contextual Teaching and Learning (CTL) is an educational process that aims to help students see meaning in the academic material they are studying by connecting the academic subjects they study with the context in their daily lives, namely with the context of their personal, social and social circumstances. their culture. To achieve this goal, the system includes the following eight components: making meaningful connections, doing meaningful work, conducting selfregulated learning, cooperating, thinking critically and creatively, helping individuals to grow and develop, achieving high standards, and use authentic assessment.

\subsection{CTL Implementation Steps}

Broadly speaking, the steps for implementing CTL in the classroom so that learning can take place are:

1. Develop the idea that children will learn more meaningfully by working alone, and constructing their own new knowledge and skills.

2. Conduct as far as possible inquiries for all themes/topics.

3. Develop students' curiosity by asking questions.

4. Create a learning community (learning in groups).

5. Present the model as an example of learning.

6. Reflect at the end of the meeting.

7. Do the actual assessment in various ways.
Contextual learning based on constructivism is an update to traditional learning which has been more behavioral/structural in nature.

\subsection{Macromedia Flash}

Along with technological advances, the media that can be used are also increasingly diverse, especially since multimedia technology has increased rapidly lately. One of the most interesting and concrete media is flash-based media, namely macromedia flash. With this media, the learning process becomes more interesting, abstract concepts can be explained concretely and with more colorful animated displays.

Nur Hadi Waryanto (Ceria Andespi: 25) stated that Macromedia Flash is software that has superior ability to display multimedia advertising, a combination of graphics, animation, sound, and user interactivity. Flash is a standard application program for professional authoring tools used in the creation of interactive and dynamic multimedia packages, website animations, and games.

\section{METHOD}

The type of research used in this research is descriptive qualitative research. Denzin and Lincoln (in Moleong, 2017) state that "qualitative research is research that uses a natural setting that uses a natural setting, with the intention of interpreting phenomena that occur and is carried out by involving various existing methods". This research was carried out at Al-Hikmah Private Junior High School Medan, Class VIII in the 2020/2021 Academic Year, with a schedule coordinated with school activities to be carried out from July 2020 to December 2020.

The subjects in this study involved class VIII students of Al-Hikmah Private Junior High School Medan who were given learning treatment using a contextual teaching and learning model in the odd semester of the 2020/2021 academic year with 35 students. Then based on the results of the problem- solving and mathematical communication ability tests that were tested on students who were filled in by students, they were appointed as subjects to be interviewed.

Appointment of subjects who are subjected to interviews to see the student's answer process is appointed based on analysis (observations) of the grouping of students' mathematical problem solving and communication ability levels, and based on a review of the contextual teaching and learning model of each student. To discuss students' errors and difficulties in solving students' mathematical problem solving abilities. Appointment of interview subjects for errors and difficulties is by looking at student answer sheets with errors in the three aspects of the indicators of students' 
mathematical problem solving abilities and based on a review using the CTL model aimed at each student.

The criteria for appointing the interview subject are errors and difficulties based on the error glasses on the indicators of mathematical problem solving abilities, and the CTL model. Based on each point of view of learning media and errors in the three aspects of the indicators of mathematical problem solving abilities, subjects will be subject to interviews. Then, based on the dominant pattern of answers, students will be selected as subjects who are subject to interviews and will be asked several questions regarding errors and difficulties.

Interview subjects were conducted based on a review of each classification of answers, then an interview was conducted on the student with the consideration that the student was considered a person who could provide clear, correct, and reliable data. Sugiyono (2016) explains "if the data obtained does not feel complete, then another subject will be subjected to an interview to be interviewed in the hope of providing more complete information, and so on, the subject will continue to be raised and data will continue to be collected through the interview process until the data is considered saturated." So that it can be concluded from the analysis of problem solving abilities using the CTL model assisted by macromedia flash.

The object of this research is the ability to solve mathematical problems using CTL assisted by macromedia flash. Objects in this study, among others, can be seen from the results of students' mathematical problem solving ability tests, namely through student answer sheets, the use of student learning media can be seen from the learning media questionnaire given to students, and through interviews, namely transcripts of tape-recorder recordings to students.

\subsection{Research Mechanism}

As explained in the type of research, this research is a qualitative research that aims to describe the ability to solve mathematical problems using a contextual teaching and learning model assisted by macromedia flash. The mechanism used in this research includes three stages, namely: (1) The stage of preparing learning tools and research instruments; (2) The validation phase of learning tools and research instrument trials; (3) The stage of conducting research and data analysis. Each stage is designed so that valid and reliable data is obtained according to the research objectives. The following is the design of each stage in the research.

At the expert validation stage of the learning device, validators from experts, namely the Postgraduate Lecturer at the State University of Medan, focused on content, language, and conformity to the learning model. The validation criteria of experts on learning tools and research instruments can be seen in Table 3.1.
Table 3.1. Interpretation Validity

\begin{tabular}{|c|c|}
\hline $\begin{array}{c}\text { Correlation } \\
\text { Coefficient }\end{array}$ & Interpretation \\
\hline $1 \leq \mathrm{V}_{\mathrm{a}}<2$ & Invalid \\
\hline $2 \leq \mathrm{V}_{\mathrm{a}}<3$ & Invalid \\
\hline $3 \leq \mathrm{V}_{\mathrm{a}}<4$ & Sufficiently Valid \\
\hline $4 \leq \mathrm{V}_{\mathrm{a}}<5$ & Valid \\
\hline $\mathrm{V}_{\mathrm{a}}=5$ & Very Valid \\
\hline & (Sinaga, 2007) \\
\hline
\end{tabular}

From the results of the validation carried out by experts, it can be concluded as Table 3.2. with a valid validation level.

Table 3.2. Interpretation of Learning Tool Validity

\begin{tabular}{|l|l|c|c|}
\hline No. & \multicolumn{1}{|c|}{ Valued Objects } & $\begin{array}{c}\text { Average } \\
\text { Value Total } \\
\text { Validity }\end{array}$ & $\begin{array}{c}\text { Validation } \\
\text { Level }\end{array}$ \\
\hline 1. & $\begin{array}{l}\text { Learning } \\
\text { Implementation } \\
\text { Plan (RPP) }\end{array}$ & 4,5 & Valid \\
\hline 2. & $\begin{array}{l}\text { Student Activity } \\
\text { Sheet (LAS) }\end{array}$ & 4,4 & Valid \\
\hline 3. & $\begin{array}{l}\text { Student Book } \\
\text { (BS) }\end{array}$ & 4,5 & Valid \\
\hline
\end{tabular}

In addition, the validation of the research instrument was carried out by statistical tests (empirically) to see the validity, reliability so that the validity of the research instrument was getting better.

\subsection{Implementation of Research and Data Analysis Phase}

After compiling learning tools and research instruments as well as validation and testing, then proceed with conducting research and data analysis. The implementation of data analysis cannot be separated because each data obtained is immediately analyzed to be considered for the next stage. The stages of the research carried out along with the analysis included the implementation of learning, tests of giving student response questionnaires, problem solving abilities and mathematical communication of students, interviews with students, and interviews with teachers.

The initial stage is to provide student activity sheets that are displayed through the macromedia flash application. Student activity sheets displayed through the macromedia flash application were given to all major subjects in the study. The second stage is the implementation of learning. At this stage, learning mathematics is carried out by learning in two meetings ( $5 \times 40$ minutes) with a schedule that is adjusted to the schedule of school activities in the selected class on the main subject of research by using all learning tools that have been prepared previously. 
The next stage is the stage of giving a test of mathematical problem solving ability. This test was carried out to obtain data on students' mathematical problem solving abilities. This test was given to all subjects in the study. then an analysis of the test results (student answer sheets).

After the analysis of the mathematical problem solving ability test was obtained, it was continued at the interview stage. Interviews were conducted on research subjects that had been determined based on the results of the students' mathematical problem solving ability tests and then grouped based on the level of students' mathematical problem solving abilities and teachers who applied learning. Interviews with subjects were conducted based on the answer sheets of mathematical problem solving abilities in order to obtain data as a comparison (triangulation) against the description of the results of the answer sheets for students' mathematical problem solving ability tests and interviews with teachers were conducted to obtain comparative data (triangulation) on the descriptions of students' answer sheets and The results of the description of interviews with students then based on the data triangulation will be presented and then conclusions are drawn about students' mathematical problem solving abilities in terms of the CTL model assisted by Macromedia Flash.

Table 3.3. Results of the Calculation of the Validity of Items

\begin{tabular}{|c|c|c|c|c|}
\hline $\begin{array}{c}\text { No } \\
\text { Question }\end{array}$ & $\mathbf{r} \mathbf{x y}$ & $\mathbf{t}$ hit & $\mathbf{t}$ table & Interpretation \\
\hline 1 & 0,768 & 11,388 & 2,011 & Valid \\
\hline 2 & 0,885 & 14,599 & 2,011 & Valid \\
\hline 3 & 0,929 & 21,505 & 2,011 & Valid \\
\hline 4 & 0,722 & 8,678 & 2,011 & Valid \\
\hline
\end{tabular}

\section{Test Reliability Test}

A measuring instrument (instrument) has good reliability if the measuring instrument has reliable consistency even though it is done by anyone (in the same level), wherever and whenever they are. The results of the calculation of the reliability coefficient, then interpreted referring to the opinion of Arikunto (2012) as shown in Table 3.4.

Table 3.4. Interpretation of Test Reliability

\begin{tabular}{|c|c|}
\hline Correlation Coefficient & Interpretation \\
\hline $0,80<\mathrm{r}_{11} \leq 1,00$ & Very High \\
\hline $0,60<\mathrm{r}_{11} \leq 0,80$ & High \\
\hline $0,40<\mathrm{r}_{11} \leq 0,60$ & Enough \\
\hline $0,20<\mathrm{r}_{11} \leq 0,40$ & Low \\
\hline $0,00<\mathrm{r}_{11} \leq 0,20$ & Very Low \\
\hline
\end{tabular}

(Arikunto, 2012)
In this study, the test is said to be reliable if it has sufficient minimum reliability. The qualitative model used in this study follows the concept given by Miles and Huberman. As stated, Sugiyono (2016) that "consists of three flow of activities that occur interactively and take place continuously until complete. Activities in data analysis are: Data Reduction, Data Display, and Conclusion. For more details on the process can be seen in Figure 3.1.

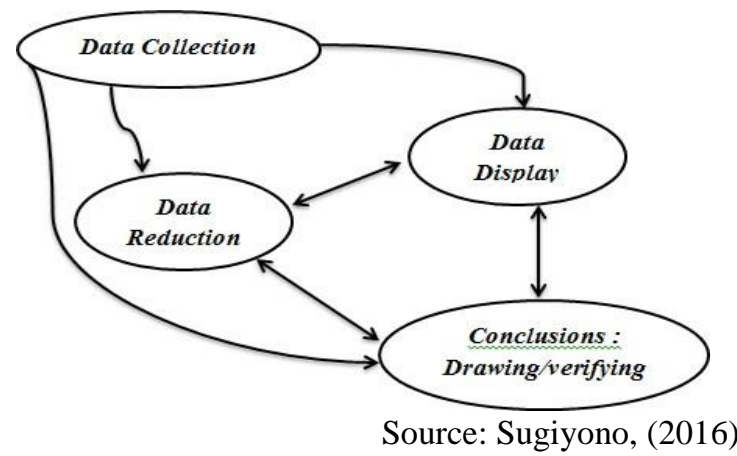

Figure 1. Data reduction, data display, and Conclusion

\section{RESULT AND DISCUSSION}

The purpose of this study was to obtain information about learning mathematics in students' mathematical problem solving abilities based on the contextual teaching and learning model assisted by macromedia flash. This research was carried out at the Al-Hikmah Private Junior High School Medan in grades VIII - 4. The implementation of learning for two meetings using valid and reliable learning tools based on expert validation and statistical calculations.

Analysis of mathematical problem solving skills based on the contextual teaching and learning model for class VIII - 4 assisted by macromedia flash was carried out by analyzing the results of mathematics problem solving ability tests, interview results and observation sheets of student activities carried out with selected subjects.

Data analysis of the results of the mathematical problem solving ability test, interview results, and student activity observation sheets were carried out with data analysis steps according to Sugiyono, (2016: 247), namely "Data Collection (Data Collection), Data Reduction (Data Reduction), Data Presentation (Data Display), and Drawing Conclusions (Conclusion)". Data collection activities in this study were collecting all the required data in the form of students' mathematical problem solving ability test results and student activity observation sheets according to the chosen subject, also rewriting the results of interview activities which were still in the form of audio into written form to facilitate analysis. 
The mathematical problem solving ability test consists of 4 questions and the students' mathematical communication skills consist of 3 questions in the form of descriptions with function material. From the results of the validation and testing of the instrument, it was found that the 7 questions could be used with a few revisions, were valid and reliable in the very high category. The mathematical problem solving and mathematical communication ability test was held on Saturday, November 14, 2020 for 90 minutes. Tests of mathematical problem solving skills and mathematical communication skills were carried out by students individually and honestly and were supervised directly by researchers and mathematics teachers at Al-Hikmah Private Junior High School Medan.

The level of students' mathematical problem solving ability can be seen in Table 4.1

Table 4.1. Level of Students' Mathematical Problem Solving Ability

\begin{tabular}{|l|c|c|c|}
\hline Value Interval & $\begin{array}{c}\text { Number } \\
\text { of } \\
\text { Students }\end{array}$ & $\begin{array}{c}\text { Percent } \\
\text { age }\end{array}$ & $\begin{array}{c}\text { Assessme } \\
\text { nt Criteria }\end{array}$ \\
\hline $0 \leq$ SKPM $<50$ & 21 People & $60 \%$ & Low \\
\hline $50 \leq \mathrm{SKPM}<80$ & 11 People & $31,43 \%$ & Medium \\
\hline $80 \leq \mathrm{SKPM} \leq 100$ & 3 People & $8,57 \%$ & High \\
\hline
\end{tabular}

Based on the results of the tests given to measure students' mathematical problem solving abilities, the level of students' mathematical problem solving in each indicator of students' mathematical problem solving is described as follows:

\subsection{Understanding the Problem (Indicator 1)}

The ability to understand problems in mathematical problem solving is related to students' ability to write down what is known and what is asked of the given problem. The value of the ability to understand the problem is obtained by sorting out student answer scores related to the measurement of indicators of understanding problems in solving mathematical problems. Based on the assigned rubric, the maximum value for the indicator of understanding the problem of each question is 4 and the minimum value is 1 . Of the 4 (four) problem- solving ability test questions given, each question (maximum score of 4 ) is converted to a maximum value of 25 , so that the maximum value obtained is 4 questions $\mathrm{x} 25=100$. The distribution of the ability to understand problems in solving mathematical problems is presented as in Table 4.2 .

Table 4.2. Description of Problem Understanding Ability

\begin{tabular}{|c|c|c|c|}
\hline Value Interval & $\begin{array}{c}\text { Number } \\
\text { of } \\
\text { Students }\end{array}$ & $\begin{array}{c}\text { Percen } \\
\text { tage }\end{array}$ & $\begin{array}{c}\text { Assessm } \\
\text { ent } \\
\text { Criteria }\end{array}$ \\
\hline $0 \leq \mathrm{KPMM}<65$ & 5 People & $14,2 \%$ & Low \\
\hline $65 \leq \mathrm{KPMM}<80$ & 13 People & $37,1 \%$ & Medium \\
\hline $80 \leq \mathrm{KPMM} \leq 100$ & 17 People & $48,5 \%$ & High \\
\hline
\end{tabular}

\subsection{Ability to Plan Problems (Indicator 2)}

The ability to plan problems in solving mathematical problems is related to the ability of students to make mathematical models of the problems given and to provide correct and complete explanations. The value of the ability to understand the problem is obtained by sorting out student answer scores related to the measurement of indicators of planning problems in solving mathematical problems. Based on the specified rubric, the maximum value for the Indicator of planning problems for each question is 4 and the minimum value is 1 . Of the 4 (four) problem- solving ability test questions given, each question (maximum score of 4 ) is converted to a maximum value of 25 , so that the maximum value obtained is 4 questions $x 25=100$. The distribution of the ability to plan problems in solving mathematical problems is presented as in Table 4.3.

Table 4.3. Description of Problem Planning Ability

\begin{tabular}{|c|c|c|c|} 
Value Interval & $\begin{array}{c}\text { Number } \\
\text { of } \\
\text { Students }\end{array}$ & $\begin{array}{c}\text { Average } \\
\text { Percenta } \\
\text { ge }\end{array}$ & $\begin{array}{c}\text { Assessm } \\
\text { ent } \\
\text { Criteria }\end{array}$ \\
\hline $0 \leq$ KPMM $<65$ & 8 People & $22,8 \%$ & Low \\
\hline $65 \leq$ KPMM $<80$ & 11 People & $31,4 \%$ & Medium \\
\hline $80 \leq$ KPMM $\leq 100$ & 16 People & $45,7 \%$ & High \\
\hline
\end{tabular}

\subsection{Ability to Solve Problems (Indicator 3)}

The ability to solve problems in solving mathematical problems is related to using the right strategy in solving problems and doing calculations correctly and correctly. The value of problem solving ability is obtained by sorting out student answer scores related to the measurement of problem solving indicators in mathematical problem solving. Based on the rubric that has been set, the maximum value for the indicator of solving problems for each question is 4 and the minimum value is 1 . Of the 4 (four) problem solving ability test questions given, each question (maximum score of 4 ) is converted to a maximum value of 25 , so that the maximum value obtained is 4 questions x $25=100$. The distribution of problem solving abilities in mathematical problem solving is presented as in Table 4.4.

Table 4.4. Description of Problem Solving Skills

\begin{tabular}{|c|c|c|c|} 
Value Interval & $\begin{array}{c}\text { Number } \\
\text { of } \\
\text { Students }\end{array}$ & $\begin{array}{c}\text { Average } \\
\text { Percent } \\
\text { age }\end{array}$ & $\begin{array}{c}\text { Assessm } \\
\text { ent } \\
\text { Criteria }\end{array}$ \\
\hline $0 \leq \mathrm{KPMM}<65$ & 14 People & $40 \%$ & Low \\
\hline $65 \leq \mathrm{KPMM}<80$ & 10 People & $28,5 \%$ & Medium \\
\hline $80 \leq \mathrm{KPMM} \leq 100$ & 9 People & $25,7 \%$ & High \\
\hline
\end{tabular}

\subsection{Recheck Ability (Indicator 4)}

The ability to re-examine mathematical problem solving is related to checking the solution correctly and correctly. The value of the ability to re-examine is obtained by sorting out the scores of students' answers 
related to the measurement of indicators of re-examining in solving mathematical problems. Based on the rubric that has been set, the maximum value for the indicator for checking back from each question is 4 and the minimum value is 1 . Of the 4 (four) problem-solving ability test questions given, each question (maximum score of 4 ) is converted to a maximum value of 25 , so that the maximum value obtained is 4 questions $x 25=100$. The distribution of the ability to re-examine in solving mathematical problems is presented as in Table 4.5.

Table 4.5. Description of Recheck Ability

\begin{tabular}{|c|c|c|c|}
\hline Value Interval & $\begin{array}{c}\text { Number } \\
\text { of } \\
\text { Students }\end{array}$ & $\begin{array}{c}\text { Average } \\
\text { Percent } \\
\text { age }\end{array}$ & $\begin{array}{c}\text { Assessme } \\
\text { nt Criteria }\end{array}$ \\
\hline $0 \leq \mathrm{KPMM}<65$ & 30 People & $85,7 \%$ & Low \\
\hline $65 \leq \mathrm{KPMM}<80$ & 5 People & $14,2 \%$ & Medium \\
\hline $80 \leq \mathrm{KPMM} \leq 100$ & 0 People & $0 \%$ & High \\
\hline
\end{tabular}

In general, the results of the students' mathematical problem solving ability tests on all research subjects can be described based on the indicators of mathematical problem solving abilities in the following Table 4.6.

Table 4.6. Indicators of Mathematical Problem Solving Ability

\begin{tabular}{|l|l|l|c|}
\hline \multirow{2}{*}{ No } & \multicolumn{1}{|c|}{$\begin{array}{c}\text { Indicators of } \\
\text { Mathematical } \\
\text { Problem Solving }\end{array}$} & $\begin{array}{c}\text { Ability } \\
\text { Indicators of } \\
\text { Student Errors }\end{array}$ & $\begin{array}{c}\text { Many } \\
\text { Students }\end{array}$ \\
\hline 1 & $\begin{array}{l}\text { Understanding the } \\
\text { Problem }\end{array}$ & Facts Error & 7 \\
\cline { 3 - 4 } 2 & Principle Error & 7 \\
\hline 3 & $\begin{array}{l}\text { Planning to Solve } \\
\text { Operation }\end{array}$ & $\begin{array}{l}\text { Conceptual } \\
\text { Errors }\end{array}$ & 15 \\
\hline 4 & $\begin{array}{l}\text { Rechecking the } \\
\text { Solution }\end{array}$ & $\begin{array}{l}\text { Operation } \\
\text { Error }\end{array}$ & 21 \\
\hline
\end{tabular}

\section{CONCLUSION}

There are 3 students $(8.57 \%)$ who have a high level of mathematical problem solving ability; 11 students $(31.43 \%)$ have a moderate level of mathematical problem solving ability; 21 students $(60 \%)$ had a low level of mathematical problem solving ability. From the results of the answers on the students' answer sheets, it can be described that students with high mathematical problem solving abilities provide answers to each question in a sequential and correct manner in accordance with the indicators of mathematical problem solving abilities asked in the questions. Students in this category complete all 4 test questions. For students with moderate mathematical problem solving abilities, they are only able to solve 3 questions out of 4 test questions. The student gave answers to each question in sequence according to the indicators of mathematical problem solving ability asked in the questions. However, there are students who are not right in answering the questions. For students in the low category, they can only answer a maximum of 2 questions from the 4 questions given, there are even students who do not write down the answers at all. The pattern of answers of students who can solve the 2 questions varies, some are able to answer all the questions, some are only able to answer some of the questions.

After analyzing the student's answer process descriptively, the student's answer process to the math problem solving test can be concluded as follows:

- In the first indicator, namely understanding the problem, it was found that 15 students were able to solve the questions correctly, 13 students were able to solve the questions correctly but there were deficiencies, and 7 students were unable to solve the questions properly.

- In the second indicator, namely planning the solution, it was found that 8 students were able to solve the questions correctly, 11 students were able to solve the questions correctly but there were deficiencies, and 16 students were unable to solve the questions properly.

- In the third indicator, namely solving problem solving, it was found that 8 students were able to solve the questions correctly, 6 students were able to solve the questions correctly but there were deficiencies, and 21 students were unable to solve the questions properly.

- In the fourth indicator, namely re-examining the solution, it was found that 4 students were able to solve the questions correctly, 6 students were able to solve the questions correctly but there were deficiencies, and 25 students were unable to solve the questions properly.

After analyzing the students' errors and difficulties descriptively, then the students' errors and difficulties in solving math problem solving ability tests can be concluded as follows:

- In the first indicator, namely understanding the problem, several difficulties were found for students (1) there were students who were able to show a good understanding of the questions, such as writing down what was known and what was asked in the question. (2) there are students who are less able to show a good understanding of questions such as writing down what is known and what is asked in the question.

- In the second indicator, namely planning solutions, in planning solutions there are several difficulties experienced by students (1) there are students who are able to make plans/strategies or methods used and lead to the correct solution in solving problems with the mathematical model that has been described in the first indicator. . (2) there are students who are less able to plan solutions and are unable to make plans/strategies or methods used and lead to the correct solution in solving problems with the 
mathematical model that has been described in the first indicator. (3) students still have difficulty in solving problems of mathematical problem solving abilities on indicators of planning solutions. The difficulty of students in expressing concepts is caused by the inability of students to make plans/strategies or the methods used.

- In the third indicator, namely solving problem solving, a problem was found that there were students who were unable to solve mathematical problems by doing calculations, and proving that the steps/plans chosen were correct. Students' difficulties in solving the right problems were caused by the inability of students to determine the completion plan. problem used.

- In the fourth indicator, namely re-examining the completion, students experienced many difficulties and were unable to check the completion (evaluating or testing the answers), checking whether the answers obtained made sense, were incomplete or unclear, the overall appearance was neat, accurate and easy to read. However, there are some students who are able.

\section{AUTHORS' CONTRIBUTIONS}

The title "AUTHORS' CONTRIBUTIONS" should be in all caps.

\section{ACKNOWLEDGMENTS}

The title "ACKNOWLEDGMENTS" should be in all caps and should be placed above the references. The references should be consistent within the article and follow the same style. List all the references with full details.

\section{REFERENCES}

[1] Andespi, C. (2016). Development of Pythagorean Material Interactive Mathematics Learning Media with Contextual Approach for Class VIII Junior High School. Essay. Yogyakarta: Department of International Mathematics Education, FMIPA, UNY

[2] Ansari, B. (2016). Mathematical Communication: Thinking Strategies and Learning Management. Banda Aceh: PenNa

[3] Arikunto. (2010). Research Procedure: A Practical Approach. Jakarta: Rineka Cipta

[4] Arsyad, A. (2013). Learning Media. Jakarta: PT Raja Grafindo Pustaka.

[5] Aufa, Saragih \& Minarni. 2016. Development of Learning Devices through Problem Based Learning Model Based on the Context of Aceh Cultural to Improve Mathematical Communication Skills and
Social Skills of SMPN 1 Muara Batu Students. Journal of Education and Practice.Vol.7, No.24,ISSN 2222-1735 (Paper) ISSN 2222-288X (Online), www.iiste.org

[6] Dahar, M. (2014) Students' Understanding of Quadrilateral Concepts Based on Van Hiele Theory. Proceedings of the National Mathematics Seminar at the University of Jember, 19 November 2014. Accessed 11 April 2014.

[7] Ministry of National Education. 2006. Competency Standards and Basic Competencies. Jakarta: Research and Development Center for Curriculum Center.

[8] Ministry of National Education. 2007. Policy Study of Mathematics Subject Curriculum. Jakarta: Research and Development Center for Curriculum Center.

[9] Dimyati and Mujiono, 2002. Learning and Learning. Jakarta: Rineka Cipta.

[10] Djamarah, S, B. 2002. Psychology of Learning. Jakarta: Rineka Cipta.

[11] Fauzan, Ahmad. 2011. Module 1 Evaluation of Mathematics Learning. Math Problem Solving. Mathematics evaluation.net: Padang State University.

[12] Fadilah N, Surya E. Comparison of Students' Mathematical Problem Solving Ability Using Eliciting Activities and Problem Based Learning Models in Class VIII SMP Negeri 38 Medan, Inspirational, Vol. 3, No. April 1, 2017.

[13] Fuadi, Minarni \& Banjarnahor. 2017. Analysis Of Students' Mathematical Problem Solving Ability In Ix Grade At Junior High School Ar-Rahman Percut. International Journal of Novel Research in Education and Learning Vol. 4, Issue 2, pp: (153159), Month: March-April 2017, ISSN 2394-9686 Available at: www.noveltyjournals.com

[14] Hamalik, Oemar. 2008. Teaching Planning Based on a Systems Approach. Jakarta: Earth Literacy.

[15] Johnson, Elaine B. (2007). Contextual Teaching \& Learning Makes Teaching and Learning Activities Fun and Meaningful. Bandung: MLC.

[16] Khairani, M. et al. (2016). Development of Learning Media in the Form of Macromedia Flash Tube Material for Middle School Class IX. Journal of Applied Science and Technology. Research of Applied Science and Education V10.i2 (95-102)

[17] Marzuki, (2012). "Integrating Character Education in Learning in Schools” FIS-UNY. Yogyakarta. 
[18] Milles \& Huberman. 1992. Qualitative Data Analysis (about new methods). Jakarta: UI- Press.

[19] Minarni, Ani. 2017. On Eight Grade Students Understanding in Solving Mathematical Problems. Asian Social Sciences; Vol. 13, No. 12; 2017 ISSN 1911-2017 E-ISSN 1911- 2025 Published by Canadian Center of Science and Education

[20] Moleong, L. J. 2017. Qualitative Research Methodology. Bandung: PT. Youth Rosda Karya.

[21] National Council of Teachers of Mathematics. 2000. Mathematics Assessment a Practical Handbook for grades 6-8. Reston: NCTM.

[22] Nurhadi. (2002). Contextual Approach (CTL). Malang: State University of Malang.

[23] NCTM (2000). Contextual Learning. [On line]. Available:http://www.learner.org/channel/courses/t each ingmath/gradesk_2/session_03/sectio_03_a.h tml. [10 september 2015]

[24] Nurmanita Prima Rahmawati. (2013). Development of Interactive Multimedia- Based Learning Media with Contextual Approach for Class X Vocational High School Students on Linear Program Materials. Essay. Yogyakarta: Department of Mathematics Education, FMIPA, UNY.

[25] Purba, E. P. 2017. Analysis of the Difficulties of the Mathematical Creative Thinking Process in the Application of Problem Based Learning Model. AISTEEL 2017. Advances in Social Science, Education and Humanities Research, volume 104, pp: 265-268.

[26] Purba, E. P. 2017. Analysis of the Difficulties of Students' Mathematical Creative Thinking Process in the Application of Problem Based Learning (PBL) Models. Thesis. Medan: PPs State University of Medan.

[27] PISA 2012. 2013. Result in Focus, What 15- yearolds know and whay they can do with what they know. OECD, Program for International Student Assessment.

[28] Polya, G. 1973. How to Solve It. New York: Double day.

[29] Rusman. 2014. Learning Models: Developing Teacher Professionalism. Jakarta: Rajawali Press.

[30] Rofiqoh, Zeni. 2015. Analysis of Mathematics Problem Solving Ability of Class X Students in Discovery Learning Based on Student Learning Style. Essay. Semarang: Semarang State University.

[31] Safitri, M. et al. (2013). Development of Learning Media for Triangle Mathematics Using Macromedia
Flash for Class VII Junior High School Students. Journal of Education, Vol 14(2), 62-72.

[32] Sanjaya, W. (2013). Educational Research Types, Methods, and Procedures. Jakarta: Prenada Media Group.

[33] Saragih. Dodi, Minarni \& Mukhtar. 2018. Differences Between Student's Mathematical Problem Solving Ability and Learning Motivation Taught By Using Geogebra- Assisted Cooperative and Contextual Learning Model. Advances in Social Sciences Research Journal. Vol.5, No.10.

[34] Sanjaya. (2005). Contextual Teaching and Learning (CTL) approach. Jakarta: Rafika Media.

[35] Silberman, L. Melvi. 2006. Active Learning 101 Ways of Active Student Learning. Bandung: Nusamedia.

[36] Silver, E, A. 1997. Fostering Creativity Through Instruction Rich in Mathematical Problem Solving and Problem Posing. ZDM Volume 29 (June 1997) No. 3, pp: 75-80.

[37] Sinaga, B. 2007. PBM-B3 Model Book. Surabaya: PPs State University of Surabaya.

[38] Sugiyono. (2008). Educational Research Methods Approach Quantitative, Qualitative, and R \& D. Bandung: Alfabeta.

[39] Sugiono. 2008. Qualitative Quantitative Research Methods and R\&D. Bandung: Alphabeta.

[40] Sumiati \& Asra. 2009. Learning Methods. Bandung: Prima Discourse.

[41] Susilana, Rudi \& Riyana, Cepi. 2009. Learning Media Nature, Development, Utilization and Assessment. Bandung: Prima Discourse.

[42] Shah, Muhibbin. 2008. Educational Psychology With a New Approach. Bandung: Youth Rosda Karya.

[43] Trianto. 2009. Designing an Innovative- Progressive Learning Model. Jakarta: Kencana Prenada Media Group.

[44] Wulandari, Sinaga \& Minarni. 2018. Analysis of Students Metacognition Ability in Mathematical Problem Solving On Problem Based Learning in SMA Negeri 1 Binjai. IOSR Journal of Research \& Method in Education (IOSR-JRME) Volume 8, Issue 1 Ver. II (Jan-Feb 2018), PP 32-40. e-ISSN: 2320-7388, p-ISSN: 2320-737X, www.iosrjournals.org 